\title{
Analysis of the Difficulties of Vocational High School Teachers in Mechanical Engineering Program in Implementing 2013 Curriculum in Medan City
}

\author{
Robert Silaban ${ }^{1 *}$, Janter Simanjuntak ${ }^{1}$, Lixpen Saritua Panjaitan ${ }^{1}$ and Hidir Efendi ${ }^{1}$ \\ \{*robertsilaban@unimed.ac.id, janterps@gmail.com, lixpenpanjaitan@gmail.com, \\ hidirefendi@gmail.com
}

${ }^{1}$ Department of Mechanical Engineering, Unvesitas Negeri Medan

\begin{abstract}
This study aims to: (1) describe the level of difficulty of the teacher in planning, implementing and evaluating mechanical engineering learning; and (2) knowing what dimensions are most difficult for teachers in mechanical engineering learning. This research is a descriptive study with a quantitative approach. The population of this study were all mechanical engineering SMK teachers in the city of Medan, amounting to 36 people. Data collection techniques used are questionnaires. The data analysis technique used is statistical-descriptive analysis. Based on the results of the study showed that: (1) The level of difficulty of the teacher in the main task and function of the teacher generally included in the category of not difficult that is equal to $80.55 \%$. However, there are still some teachers in the very difficult category, which is $5.56 \%$. (2) the teacher in carrying out the stages of planning, implementing and assessing authentic learning falls into the category of not difficult. (3) the dimension that is most difficult for teachers in learning is the authentic assessment dimension; and (4) male teachers and non-government employees have more difficulty in carrying out authentic planning and assessment stages in the 2013 Curriculum.
\end{abstract}

Keywords: Teacher difficulty, mechanical engineering, 2013 curriculum

\section{Introduction}

The 1945 Constitution mandates that the establishment of the Government of the Republic of Indonesia, among others, to educate the life of the nation [1]. The government endeavors and organizes a national education system, which increases faith and piety as well as noble character in the framework of educating the life of the nation, which is regulated by the constitution. Furthermore, the Law on the National Education System states: The curriculum is a set of plans and arrangements regarding the objectives, content, and learning materials and the methods used as guidelines for the implementation of learning to achieve certain educational goals [2]. In its operation the curriculum is always changing in accordance with the times, at first the curriculum that applies is the 1947 curriculum until the last is the 2013 curriculum [3]. evelopment of the 2013 Curriculum is a further step in the development of a competency-based curriculum that was pioneered in 2004 and 2006 KTSP which includes attitudes, knowledge, and skills competencies into curriculums that in the implementation of the learning process, the approach/method recommended is to use the scientific approach/method, followed with learning models: problem based, project-based learning, 
inquiry, and discovery in all subjects. The development of the 2013 Curriculum is an advanced step in the development of a competency-based curriculum that was initiated in 2004 and the 2006 KTSP which includes integrated competencies in attitudes, knowledge and skills. In the 2013 curriculum according to the Minister of Education and Culture Regulation No. 65 of 2013 concerning Process Standards states that in the implementation of the learning process, the recommended approach/method is to use the scientific approach/method, followed by a learning model: problem-based, project-based learning, inquiry, and discovery of all subjects [4].

Implementation of the 2013 Curriculum which is based on character and competence has problems for teachers in involving all components in the learning process, starting from making Learning Implementation Plans, implementing learning using a scientific approach, assessment methods, empowering facilities and infrastructure and the work ethic of all citizens and the school environment [5].

Based on the description above, the objectives to be achieved in this study are as follows: to describe the level of difficulty of the teacher in planning, implementing and authentic assessment based on the 2013 Curriculum of Mechanical Engineering Vocational School in Medan City; and to find out which dimension is between planning, implementing, and authentic assessments that are most difficult for teachers based on the 2013 Mechanical Engineering SMK Curriculum in Medan City.

\section{Methodology}

The curriculum is the intention and hope that is poured into the form of plans and educational programs carried out by educators in schools. The curriculum is as intention and plan, while the implementation is the teaching and learning process [6], whose natural development process 2013 curriculum is based on philosophical, juridical, and conceptual [7] [5].

The characteristics of the 2013 curriculum are that in each learning the aim is to develop a spiritual, social, knowledge, skill attitude so that it can be applied by students in their daily lives. With the learning experience gained, students will apply it in various situations in schools and communities.

The 2013 curriculum is a competency-based and character-based curriculum. Characterbased and competency-based curriculum are outcomes-based curriculum and therefore curriculum development is directed at achieving competencies formulated from the Graduates Competency Standards [5] to answer the challenges of the times that are constantly changing so that students are able to compete in the future, in the national and global context [5].

Implementation is a process of applying ideas, concepts, policies, or innovations in a practical action so as to have an impact, both in the form of changes in knowledge, skills, values and attitudes [8]. Whereas according to the Oxford dictionary Advance Learner's suggests that implementation is "put something to effect" which means "the application of something that gives effect or impact" [9], which is the actualization of learning and the formation of competencies and character of learners [5].

The 2013 curriculum theme is a curriculum that can produce Indonesian people who are: productive, creative, innovative, affective through strengthening integrated attitudes, skills, and knowledge [5] 
In implementing the 2013 curriculum in line with the duties and functions of the teacher is to plan and carry out the learning process, assess learning outcomes, conduct coaching and training, as well as conduct research and community service, create an educational atmosphere that is meaningful, fun, creative, dynamic, and dialogical, has professional commitment to improve the quality of education, and set an example and maintain the good name of the institution, profession, and position in accordance with the trust given to him, have minimum qualifications and certification in accordance with the level of authority to teach, physically and spiritually healthy, and have the ability to realize goals National Education [2].

In line with the main duties and functions of the teacher in Law Number 14 of 2015 concerning Teachers and Lecturers, the teacher is a professional educator with the main task of educating, teaching, guiding, directing, training, evaluating, and evaluating students in early childhood education through formal education, basic education, and secondary education [10]. Teacher professionalism is a condition, direction, value, purpose, and quality of an expertise and authority in the field of education and teaching related to one's work that becomes a livelihood [11]. In carrying out the duties and functions as a professional teacher the teacher has difficulties which is a certain condition which is characterized by the obstacles in achieving the goal, so that it requires more effort to overcome. Difficulties experienced by teachers are inseparable from the process of implementing the teaching that takes place in the classroom [12] [13].

Research conducted by Anna Silviana Muslimah (2015), the most difficult thing in the implementation of the 2013 Curriculum is the dimension of authentic assessment; and male teachers and non-civil servant teachers are more difficult in carrying out the stages of planning and implementing the 2013 Curriculum economic learning [14]. Then the research conducted by Bagus Prasetyo and Winarno Dwi Rahardjo (2015) said that the implementation of the 2013 curriculum was not optimal [15]. Similarly, the findings of Ika Krisdiana, Davi Apriandi, and Reza Kusuma show that the greatest difficulty level of teachers in solving mathematical problems is $40 \%$ of teachers lack understanding about the objectives of the 2013 curriculum and scientific approach, $50 \%$ of mathematics teachers have difficulty in designing learning that emphasizes observation and experiment [16]. The thinking paradigm built in this paper is presented in Figure 1 below.

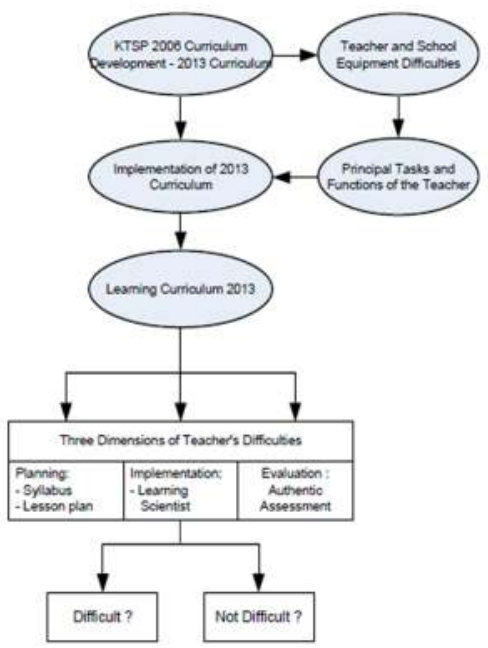

Fig. 1. Thinking Paradigm 
This research is a descriptive study, which seeks to describe and explain the objects that have been implemented in State Vocational 2, State Vocational High Schools 4, Vocational High Schools, Exemplary Private Vocational Schools and Raksana Vocational High Schools in August-September 2017. This research variable is the level of difficulty The teacher is based on the 2013 Curriculum, which means things that prevent the teacher from carrying out the learning according to the 2013 Curriculum. The level of difficulty of the teacher in carrying out learning according to the 2013 Curriculum is measured based on three dimensions of difficulty, namely planning includes the preparation of the Learning Implementation Plan and syllabus, the implementation of the scientific approach, and authentic assessment, which is captured through questionnaires or questionnaires that have been validated and valid for the sampling technique [17] The population consists of: subject/object that has certain qualities and characteristics set by the researcher to be studied and then drawn conclusions [18]. The population in the study is all public and private vocational schools in Medan that have implemented curriculum 13.

The sample is a part or representative of the population under study [19], from 15 schools that use the 2013 curriculum, there are 5 schools with mechanical engineering expertise programs with 36 teachers with 31 male and 5 female respondents. The data used in this study is primary data. Primary data sources are data sources that directly provide data to data collectors [18]. So, in obtaining this data is done directly to the Mechanical Engineering Vocational Teachers in Medan City and analyzed with descriptive statistics.

\section{$3 \quad$ Result and Discussion}

\subsection{Data Analysis of Teacher Difficulties in Tasks Teacher Principles and Functions}

The results of the data analysis of teacher difficulties in the main tasks and functions of teachers, the categories of tendencies are presented in Figure 2:

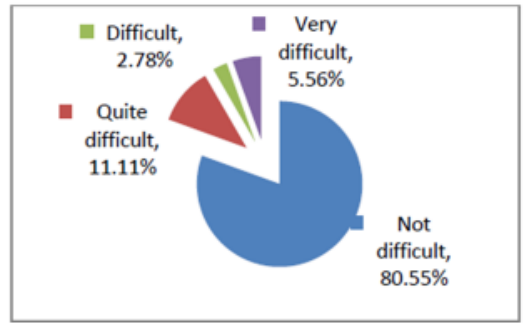

Fig. 2. Trend Category of Difficulty in Main Duty and Teacher Functions.

\subsection{Analysis of Data on Teacher Difficulties in Implementation of 2013 Curriculum}

Trend categories of teacher difficulty level in the implementation of the 2013 curriculum are presented in Figure 3 below:

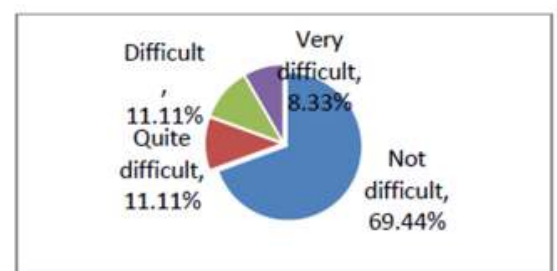

Fig. 3. Trend Category of Teacher Difficulty in Implementation 2013 curriculum 
The results of measuring the level of difficulty of Mechanical Engineering SMK teachers based on the 2013 curriculum implementation for each dimension of difficulty (planning, implementation, and learning assessment) are as follows:

\subsubsection{Dimension Planning Data Analysis}

The results of the category analysis of the level of difficulty for planning dimensions are presented in Figure 4 below:

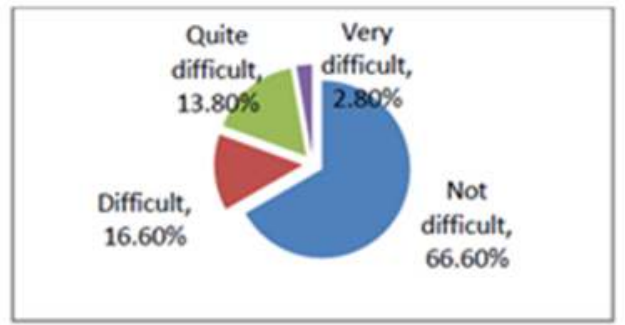

Fig. 4. Trend Categories of Difficulty in Planning Dimensions.

\subsubsection{Analysis of Implementation Dimension Data}

The results of the analysis of the category of difficulty level tendencies for the implementation dimensions are presented in Figure 5 below:

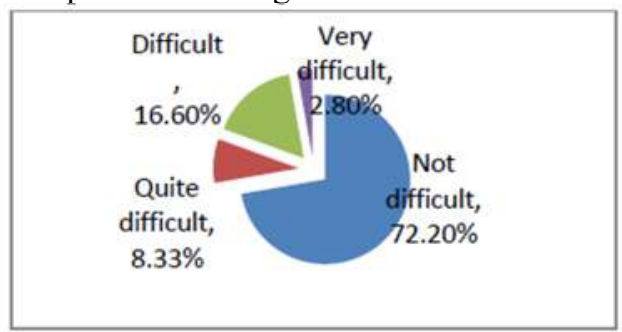

Fig. 5. Trend Categories of Difficulty in Implementation Dimensions

\subsubsection{Analysis of Assessment Dimension Data}

The results of the analysis of the category of difficulty level tendency for the implementation dimensions are presented in Figure 6 below:

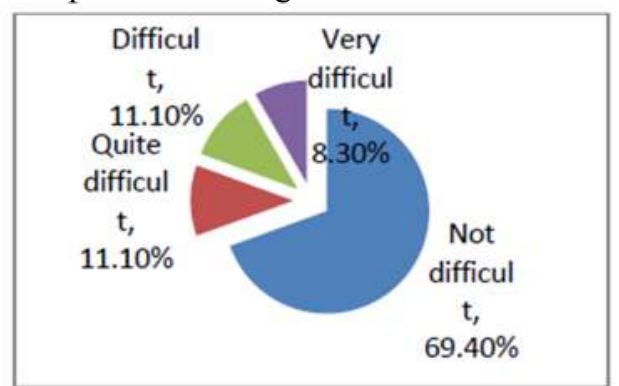

Fig. 6. Trend Categories of Difficulties in Evaluation Dimensions. 


\subsubsection{Percentage Description Frequency of each Difficulty Level Category}

The results of the overall level of difficulty are clearer, namely the combination of the planning dimension (preparation of the Learning Implementation Plan and syllabus), the dimensions of the implementation of scientific learning, and the dimensions of authentic assessment are in the following figure 7 :

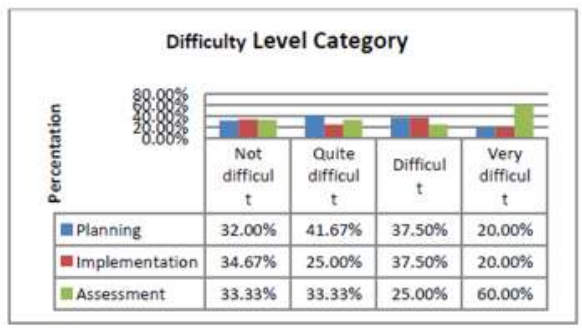

Fig. 7. Percentage description of the frequency of each difficulty level category.

\subsection{Inter-Category Data Crostabs Analysis}

Crosstabs analysis to determine the relationship between categorical variables / mechanical engineering teacher identities with the difficulty level of each learning dimension is presented as follows.

\subsubsection{Gender}

The description of the results of crostabs data analysis between categories based on male and female sex is presented in the following figure 8:

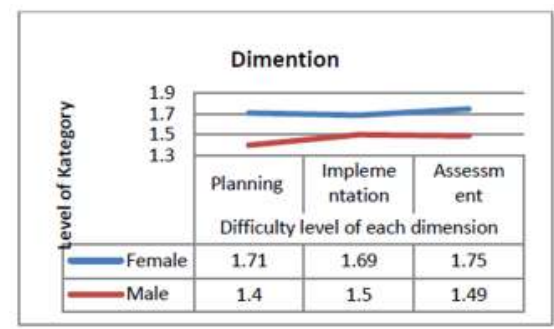

Fig. 8. Description of Crostabs Data Analysis Results Between Categories by Gender.

\subsubsection{Educational Background}

Description of the results of crostabs analysis of data between categories based on educational background is presented in the following figure 9 .

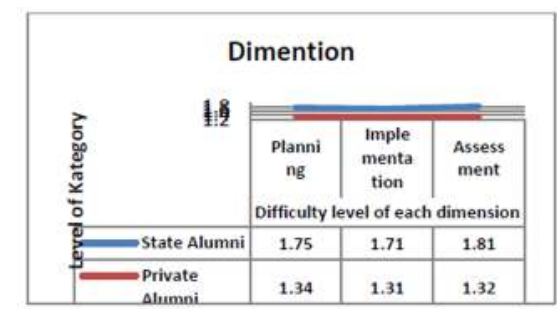

Fig. 9. Description of Results of Crostabs Data Analysis Between Categories Based on Educational Background 


\subsubsection{Employment Status}

The description of the results of crostabs analysis of data between categories based on employment status is presented in the following figure 10:

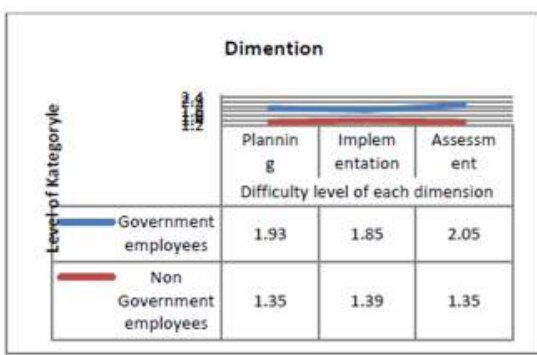

Fig. 10. Description of Results of Crostabs Data Analysis Between Categories Based on Personnel Status.

\subsubsection{School Status}

The description of the results of crostabs analysis of data between categories based on school status is presented in Figure 11 below:

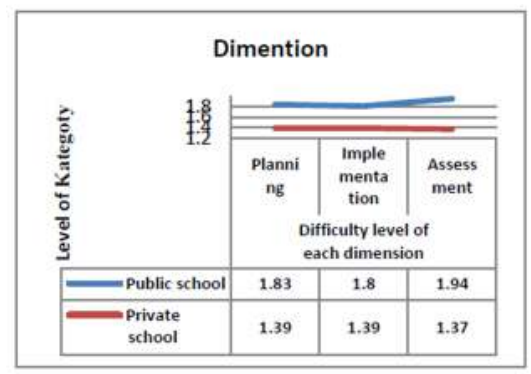

Fig. 11. Description of Results of Crostabs Data Analysis Between Categories Based on School Status.

\subsubsection{Duration of 2013 Curriculum Implementation}

The description of the results of the crostabs data analysis between categories based on the duration of the 2013 curriculum implementation are presented in Figure 12 below:

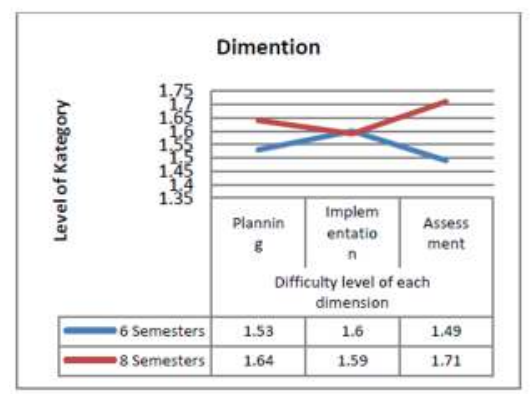

Fig. 12. Description of Results of Data Crostabs Analysis Between Categories Based on Duration of 2013 Curriculum Implementation 
From 36 Mechanical Engineering teachers who entered the research subject, in general for the level of difficulty in the main tasks and functions of the teacher the majority included in the category of not difficult as many as 29 respondents with a percentage of $80.55 \%$, then categories in a row, which is quite difficult category with the frequency of respondents as many as 4 respondents with a percentage of $11.11 \%$, a difficult category with a frequency of respondents as many as 1 respondent with a percentage of $2.78 \%$, and the category is very difficult with the frequency of respondents as much as 2 respondents with a percentage of $5.56 \%$ as presented in Figure 2.

The current 2013 curriculum as a learning guide in some schools in Medan City, especially for the five schools that became the sample of the study had used the 2013 Revised 2016 Curriculum. Of the 36 Mechanical Engineering teachers who were included in the research subject, 27 teachers claimed to have implemented the 2013 Curriculum for eight semesters, and the remaining 9 teachers claimed to have just implemented the 2013 Curriculum for six semesters.

From the results of the study, it can be seen that the difficulty level of mechanical engineering teachers in conducting learning based on the 2013 curriculum in Medan City as a whole is in the not difficult category. For more details, it can be seen in Figure 3, that is, the result is $69.44 \%$ including the not difficult category, $11.11 \%$ the category is quite difficult, $11.11 \%$ is in the difficult category and $8.33 \%$ is in the very difficult category. Furthermore, the results of the research for each dimension of difficulty indicate that the difficulty level of the mechanical engineering teacher in carrying out the learning planning stages includes the preparation of RPP and syllabus, according to the 2013 curriculum is included in the not difficult category presented in Figure 4, where the percentage is not difficult is the highest of the category the other is $66.6 \%$, the category is quite difficult $13.80 \%$ while the hard percentage is only $16.6 \%$ and the category is very difficult $2.80 \%$, it is interpreted that in preparing the syllabus and RPP for learning in Medan City it is not difficult to do so.

The structure of the syllabus, Core Competencies, Basic Competencies, and subject matter in the 2013 Curriculum can still be understood well, as well as understanding the structure of the 2013 Curriculum Learning Implementation Plan. The difficult percentage of $16.6 \%$ is more in the implementation process indicators in learning scientific and compile assessment instruments with authentic techniques.

Then in carrying out the stages of the implementation of learning with the scientific approach is included in the category is not difficult picture 5 . Where the percentage is not difficult is the highest of the other categories. that is $72.2 \%$, while the percentage is quite difficult $8.33 \%$, the difficulty is $16.6 \%$ and the category is quite difficult $2.80 \%$. So, both in understanding and implementing the scientific approach in learning the teacher has no difficulty in doing so. In carrying out the stages of the core activities in learning (ranging from observing, asking questions, gathering information, and communicating) according to the 2013 curriculum's scientific approach it can still be done well. The hard percentage of $16.6 \%$ is more about the indicator of the process of carrying out scientific learning as a whole.

Furthermore, in carrying out the assessment stages of learning with authentic assessment is included in the category of not difficult can be seen in Figure 6. The percentage is not difficult is the highest of the other categories of $69.40 \%$, while the percentage is quite difficult $11.10 \%$, the difficult category of $11,1 \%$ and which is categorized as quite difficult $3.80 \%$. So, in understanding and conducting an authentic assessment of the 2013 Curriculum the teacher has no difficulty in doing so. Basic concepts of authentic assessment and content of the Competency Standards Graduates of each domain (including the realm of attitudes, skills and knowledge) in the 2013 Curriculum are not difficult to understand. Likewise in the process of 
implementing authentic assessments by teachers to students for the realm of attitudes and skills. The percentage is quite difficult to be in the process of implementing authentic assessments that are in accordance with the 2013 Curriculum assessment guidelines.

From all the results of this analysis it can be seen that the dimension that is most difficult for the teacher is the authentic assessment stage. Where the highest percentage of categories is the most difficult, which is $60 \%$, then followed by the implementation stages using the scientific approach with a fairly difficult category with a percentage of $41.67 \%$, and planning stages of difficult categories with a percentage of $37.50 \%$. The mechanical engineering teacher claimed to be quite difficult when going to do an assessment with authentic techniques.

Authentic assessment itself is an assessment that does not merely measure the competency of students' knowledge so that it is quite difficult to apply. Authentic assessment consists of a variety of assessment techniques namely, first direct measurement of students' skills related to long-term educational outcomes such as success at work. Second, an assessment of tasks that require broad involvement and complex performance. Third, process analysis is used to generate student responses to the acquisition of attitudes, skills, and knowledge available. For that authentic assessment must be able to describe what attitudes, skills, and knowledge have or have not been owned by students.

In this case, the teacher has difficulty in assessing where the grades of students must be presented in the form of letters and not numerical values as before. The assessment process begins with reviewing the syllabus as a reference in making the design and assessment criteria at the beginning of the semester. After setting the assessment criteria, the teacher chooses assessment techniques in accordance with the indicators and develops instruments and guidelines for scoring in accordance with the selected assessment techniques. After that, the assessment report form of students in accordance with the 2013 curriculum is in the form of values and/or descriptions of achievement of competencies for the results of the assessment of competencies in knowledge and skills including assessment of thematic-integrated learning outcomes. Then accompanied by a description of the attitude for the results of the competency assessment of spiritual attitudes and social attitudes.

Then the results of the teacher category relationship to the level of difficulty perceived by the teacher in conducting learning based on the 2013 Curriculum is quite influential. This is intended from crosstabs analysis which is then displayed in the form of curves, where each curve has its own pattern. Based on the analysis that male teachers and teachers who are not Civil Servants have more difficulty in carrying out authentic planning and assessment stages in the 2013 Curriculum. Then State University graduates and teachers who implement 2013 Curriculum for eight semesters have more difficulty in performing authentic assessment stages. . Meanwhile, public school teachers have more difficulties in planning and assessment stages than private school teachers.

\section{Conclusions}

Based on the research results obtained through analysis and discussion of "Difficulties Analysis of Vocational Teachers in Mechanical Engineering Expertise Programs in Implementing 2013 Curriculum in Medan City" are as follows:

a. The level of difficulty of the teacher in the main task and function of the teacher generally falls into the category of not difficult that is equal to. However, there are still some teachers in the very category. 
b. The level of difficulty of Vocational High School teachers in planning, implementing and evaluating learning based on the 2013 Curriculum in Medan City in carrying out the learning planning stages (preparation of the RPP and syllabus) is included in the not difficult category of $66.6 \%$. While the hard percentage is only $16.6 \%$. The stages of implementing learning with the scientific approach are included in the not difficult category, which is $72.2 \%$. While the hard percentage is only $16.6 \%$. the stages of learning assessment with authentic assessment are included in the not difficult category of $69.40 \%$. While the hard percentage is only $11.1 \%$. The dimensions that are most difficult for teachers in learning based on 2013 curriculum in Medan City are authentic assessment dimensions. That is, compared to the planning dimensions and the dimensions of the implementation of learning, authentic assessment is more difficult. Where the hard percentage of authentic assessment dimension is $60 \%$, planning dimension is $41.66 \%$, and implementation dimension is $34.66 \%$. In general, male teachers and non PNS teachers have more difficulty in carrying out authentic planning and assessment stages in the 2013 Curriculum. Then graduates from State Universities and private graduate teachers who implement the 2013 Curriculum for eight semesters have more difficulty in carrying out the implementation stages, authentic assessments. Meanwhile, public school teachers have more difficulties in planning and assessment stages than private school teachers. So, it should be noted that the implementation of the 2013 curriculum in Medan is better.

\section{Suggestions}

Based on the results obtained in this study, several suggestions can be submitted, namely:

1. In the field of learning planning, the teacher should further enhance the competencies in preparing the lesson plan, especially the part of designing learning assessment instruments with authentic assessment techniques that are appropriate to the 2013 curriculum. Therefore, it is expected that teachers are more active in participating in various activities that support competency development in preparing the 2013 Curriculum RPP or attend curriculum workshop.

2. In the field of learning implementation, the teacher should further improve competence in performing the stages of "reasoning" and "creating" activities during learning.

3. In the field of learning assessment, teachers should improve their competence in conducting authentic assessments, both in terms of the overall assessment and in processing and presenting grades into report cards.

4. For advanced researchers should develop research by adding a statement on the questionnaire about the reason respondents said it was difficult or not difficult in implementing the curriculum and developing research at a more diverse population level, and develop research by looking at new problems from the results of the discussions that have been in this paper, so that it can be a reference for future researchers. 


\section{References}

[1] Undang-Undang Dasar Negara Republik Indonesia "Tahun 1945 dan Amandemennya." Bandung: Fokusmedia, 2011.

[2] Undang-undang Republik Indonesia Nomor 20 Tahun 2003 Tentang Sistem Pendidikan Nasional. Jakarta: Pemerintah Republik Indonesia, 2003.

[3] D. Wirianto, "Persepektif Historis Transformasi Kurikulum di Indonesia," Islam. Stud. J., vol. 2, 2014.

[4] Peraturan Menteri Republik Indonesia Nomor 65AD Tahun 2013 Tentang Standar Proses Pendidikan Dasar dan Menengah. Jakarta: Kementerian Pendidikan dan Kebudayaan, 2013.

[5] E. Mulyasa, Pengembangan dan Implementasi Kurikulum 2013. Bandung: PT Remaja Rosdakarya, 2013.

[6] N. Sudjana, Kurikulum dan Pembelajaran. Bandung: PT Remaja Rosdakarya, 2004.

[7] Dokumen Kurikulum 2013. Jakarta: Kementerian Pendidikan dan Kebudayaan, 2012.

[8] A. Idi, Pengembangan Kurikulum: Teori dan Praktik. Gaya Media Pertama, 1999.

[9] A. S. Hornby, S. Wehmeier, and M. Ashby, Oxford Advance Learner's Dictionary. Oxford University Press, 2002.

[10] Undang-undang Republik Indonesia Nomor 14 Tahun 2005 tentang Guru dan Dosen. Presiden Republik Indonesia, 2005.

[11] E. Kunandar and M. Si, Guru Profesional. Jakarta: Rajawali Pers, 2014.

[12] M. Abdurahman, Desain Pembelajaran, Pendidikan Agama Islam. Jakarta: Misaka Ghazalai, 2005.

[13] H. Mulyadi, Diagnosis kesulitan belajar dan bimbingan terhadap kesulitan belajar khusus. Yogyakarta: Nuha Litera, 2010.

[14] A. S. Muslimah, Analisis Kesulitan Guru SMA dalam Pembelajaran Ekonomi Berdasarkan Kurikulum 2013. MGMP Kabupaten Sleman, 2013.

[15] B. Prasetyo and W. D. Rahardjo, "Implementasi Kurikukulum 2013 pada Paket Keahlian Teknik Pemesinan di SMK N Se Kota Semarang Tahun Ajaran 2014/2015,” J. Pendidik. Tek. Mesin, vol. 15, no. 1, 2015.

[16] I. Krisdiana, D. Apriandi, and R. K. Setiansyah, “Analisis Kesulitan yang Dihadapi oleh Guru dan Peserta Didik Sekolah Menengah Pertama dalam Implementasi Kurikulum 2013 pada Mata Pelajaran Matematika (Studi Kasus Eks-Karesidenan Madiun)," JIPM (Jurnal Ilm. Pendidik. Mat., vol. 3, no. 1, 2014.

[17] S. Margono, Metodologi Penelitian Pendidikan. Jakarta: Rineka Cipta, 2005.

[18] Sugiyono, Metode Penelitian Kuantitatif, Kualitatif dan R\&D. Bandung: Alfabeta, 2008.

[19] A. Suharsimi, Manajemen Penelitian. Jakarta: Rineka Cipta, 2005. 